\title{
IoT - Internet of Things \& Swarm Intelligence
}

KEYNOTE: Silvio Meira

Moderator: Salustiano Fagundes

CEO da HXD Smart Solutions / SET

Speaker: Salustiano Fagundes

CEO da HXD Smart Solutions / SET

KEYNOTE: Sílvio Meira

Chief Imagination Officer - IKEWAI / Professor Emérito - UFPE

\section{Speaker: Renato Cruz}

Editor - inova.jor

Automação e Inteligência Comercial com loT Speaker: Paulo Henrique Pichini

CEO \& President / Go2neXt Cloud Computing - Builder \& Integrator / BT Partner

Speaker: Max Leite

Diretor Inovação IOT / INTEL 


\title{
Internet \& TV
}

\section{IOT INTERNET OF THINGS \& SWARM INTELLIGENCE}

\author{
Moderator: Salustiano Fagundes \\ CEO da HXD Smart Solutions / SET
}

Em 2020 cerca de 50 bilhões de dispositivos estarão conectados à internet, tornando o trânsito mais inteligente e seguro nas grandes cidades; as redes elétricas mais otimizadas e confiáveis; e diagnosticando e prevendo - por meio de sensores de monitoramento, problemas técnicos em diversas áreas.

Nesse cenário, que movimentará cerca de US\$1,9 trilhão em negócios, máquinas vão se relacionar, comunicar e trocar informações entre si sem a intervenção humana, tendo capacidade analítica para fornecer a inteligência necessária para agilizar processos de tomada de decisões.

Essa sessão reúne especialistas que irão demonstrar que a revolução do loT (Internet of Things) e da Swarm Intelligence já começou e vai trazer impactos cada vez maiores no cotidiano de empresas e pessoas em todo o mundo.

\section{- Speaker: SALUSTIANO FAGUNDES} CEO da HXD Smart Solutions / SET

Da literatura de fiç̧ão científica (Arthur Clark, Isaac Asimov, Philip Dick), passando pelos quadrinhos (Alex Raymond, Moebius, Stan Lee \& Jack Kirby) até chegarmos ao cinema cyberpunk/pósapocalíptico visto em filmes como Exterminador do Futuro e Matrix, as fronteiras entre o que pode ser imaginado e o que pode ser construído estão cada vez mais tênues.

Chegamos a uma era onde as inovações tecnológicas já não são projetadas para uso restrito a uma ou outra área específica do conhecimento. Tudo está se relacionando com tudo. Aplicativos de software conectam diariamente bilhões de pessoas em todo o mundo e são capazes, por exemplo, de fomentar revoluções políticas, influenciar diretamente a programação de canais televisivos e reorganizar a mobilidade nas grandes cidades. As máquinas/tecnologias não são vistas mais apenas como extensões do homem, conforme nos ensinou McLuhan, mas estão evoluindo também para tornarem-se extensões de si mesmas.

Em um futuro repleto de dispositivos inteligentes, ubíquos e ambíguos, capazes de se comunicarem e analisarem grandes volumes de informações com uma velocidade e precisão nunca antes experimentada, é possível imaginarmos cenários onde a civilização tanto pode dar um virtuoso salto quântico na sua evolução quanto um vergonhoso mergulho no abismo.

- Keynote: SílVIO MEIRA

Chief Imagination Officer - IKEWAI / Professor Emérito - UFPE

Todo objeto minimamente interessante estará em rede, fornecerá dados para sistemas que estão em rede e será supervisionado e controlável a partir de lá. Do seu carro às lâmpadas da sua casa, dos sinais de trânsito à máquina que dispensa a comida do seu cachorro. A internet das coisas ou a internet de tudo -vai começar a pegar de vez neste resto de década, até porque chegamos ao ponto em que as teles não conseguem mais vender linhas (ou chips) para usuários que ainda não existem -ou que não existem mais.

Estamos na combinação entre o posicionamento ubíquo (ou a capacidade e possibilidade de localizar tudo, gente e coisas, em qualquer lugar, a qualquer hora), e a teleoperação e telepresença, a capacidade de monitorar e controlar coisas (e tomara que não dê para controlar pessoas) à distância. Isso vai implicar em investimentos em infraestrutura para esta internet das coisas, o que vai mover 
mundos, de ambientes regulatórios a novas tecnologias, incluindo novos protocolos de comunicação como o MQTT.

Haverá mais coisas na internet em 2018 do que a soma de todos os dispositivos usados por humanos hoje, como tablets e PCs. E daí para frente, claro, só vai aumentar a diferença entre coisas e pessoas em rede. Isso quer dizer muita, mas muita oportunidade nova, em novos mercados, com o nascimento de novas categorias de produtos e serviços que a maioria dos negócios, hoje, não consegue nem imaginar.

- Speaker: RENATO CRUZ

Editor - inova.jor

Em 1995 Nicholas Negroponte do MIT, publicou o clássico "Vida digital", que tinha como conceito central a diferença entre bits e átomos. O livro mostrava como o fluxo de bits (informações digitais) pelas redes de comunicação modificaria nossas vidas. E Negroponte estava certo. A internet das coisas - em que todos os objetos passam a ter capacidade de comunicação e processamento de dados - é um dos reflexos dessa revolução digital. Segundo a consultoria Gartner, em cinco anos mais de 20 bilhões de objetos - da geladeira da sua casa aos contêineres que transportam produtos pelo mundo - estarão conectados à rede.

O Brasil, segundo o MiniCom, já é o quarto maior mercado do mundo em conexões móveis entre máquinas e o número de dispositivos conectados podem chegar a 1 bilhão em 2020. De acordo com dados divulgados em 2015 pela Agência Nacional de Telecomunicações (Anatel), mais de 2,5 milhões de dispositivos que transmitem dados para sistemas, sem intervenção humana, estão em operação atualmente no País.

Apesar do otimismo a loT pode demorar a acontecer no Brasil. Em 2015 existiam somente 10 milhões de acessos móveis usados para comunicação máquina a máquina num total de 281 milhões de celulares existentes. A maioria desses chips de comunicação entre máquinas está instalada em leitores de cartões de crédito e débito e em rastreadores de veículos.

\section{- Automação e Inteligência Comercial com loT} Speaker: Paulo Henrique Pichini CEO \& President / Go2neXt Cloud Computing - Builder \& Integrator / BT Partner Nesta trilha o foco deve apontar para as futuras experiências de usuários em ambientes inteligentes e conectados. A apresentação rompe as barreiras da relação de presença do usuário em mundo físico e digital, considerando sua interação com a informação desvinculada das tecnologias, criando uma experiência sem precedentes. Readaptar e transformar esta experiência do usuário é algo que demanda tempo e processos de disseminação de cultura. Para ilustrar, demonstraremos casos reais como o de uma empresa de eletricidade e o uso da tecnologia no Sertão do Brasil, em equipe de competição do Rally dos Sertões 2016, que acontecerá em inicio de setembro. Além do carro conectado em sofisticados elementos de loT capazes de informar, localização, eventos programados e toda a telemetria do carro de competição, ainda teremos um caminhão que levará soluções de vídeo e colaboração para operar e aumentar a produtividade da equipe em meio ao maior deserto do Brasil - o Jalapão.

- Speaker: MAX LEITE

Diretor Inovação IOT / INTEL

Soluções de loT possuem um grande potencial e podem gerar US\$ 7 bilhões em negócios no país até 2020, porém as suas aplicações dependem de várias tecnologias como sensores (como acelerômetros e termômetros) para geração de dados; conectividade (Wi-Fi, 4G etc.) para transportálos; e software capazes de dar significado à imensa quantidade de dados gerados.

Um dos grandes desafios para que a loT aconteça mais rapidamente é a garantia da interoperabilidade entre os dispositivos, já que existem mais de 3.500 protocolos diferentes entre os objetos conectados, o que gera dificuldades de comunicação.

A Intel, uma das empresas globais líderes em inovação tecnológica, vem investindo nesse mercado e participa de uma mobilização com a indústria para reduzir essa complexidade e permitir o amadurecimento do loT. 

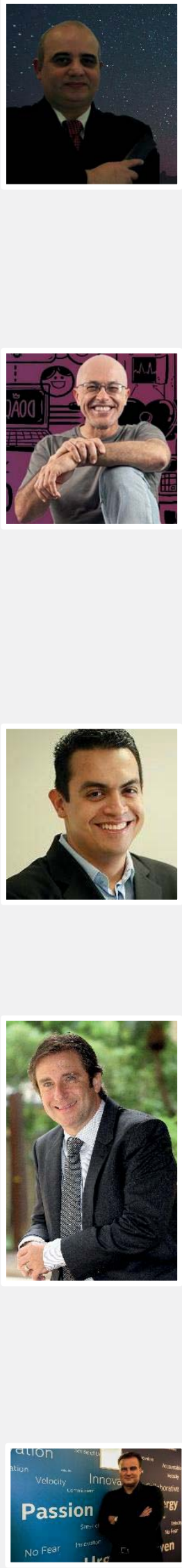

\section{MAX LEITE}

Diretor Inovação IOT - INTEL

Max Leite is Innovation Director at Intel Brazil responsible for awarded projects such as Gas Station of the Future with Petrobras and an innovative RFID tag and Intel's firs purpose built product for Brazil. He has been at Intel for over 15 years.

\section{RENATO CRUZ}

Editor - inova.jor

Senac University Center. He was a reporter and columnist for the O Estado de S. Paulo newspaper. He has published the books $O$ desafio da inovação: a revolução do conhecimento nas empresas brasileiras (published by Senac São Paulo); TV digital no Brasil: tecnologia versus política (published by Senac São Paulo) and O que as empresas podem fazer pela inclusão digital (Ethos/CDI). He holds an undergraduate degree in journalism, as well as a Master's and a Doctorate in Communication Sciences from the University of São Paulo.

\section{PAULO HENRIQUE PICHINI}

CEO \& President / Go2neXt Cloud Computing - Builder \& Integrator / BT Partner visionary, for 30 years Paulo Pichini, CEO \& President of Go2neXt Cloud Computing Builder \& technologies like digital TV, augmented reality and the Internet of Things and ICT solutions. Passionate about challenges, Pichini - who took his MBA at Harvard - is responsible for several of the most advanced projects on the Brazilian market. This is the case of companies like Alpargatas and Makro, the Anhanguera Kroton University and the banks Safra and Original. Strictness, consistency and boldness ensure that the innovation undertaken by Pichini will give cause for amazement and lead to great business results always. His extensive knowledge about hybrid and public clouds make him one of the market's most acknowledged speakers, and his presence is held in high esteem at major events like those of the operators BT (British Telecom), Embratel/Telmex and Oi. For 13 years, Paulo Pichini has taken the most advanced technology available onto the tracks of the Rally dos Sertões (the Hinterland Rally), using his $4 \times 4$ vehicle as a showcase of innovation in hostile environments. 
Leite was Global Director for Emerging Markets Group for 5 years until 2011 responsible for teams in US, Europe, Latin America, Egypt, and India. He drove dentition and commercialization of Classmate PC, giving birth to Intel Learning Series and a new consumer PC segment (Netbooks). He managed Classmate's first nationwide project (Magellan) with major public visibility where every student (1-4 grade) in Portugal got a subsidized PC. This project drove a local account, JPSC, to become Intel's largest channel account in the world and a global player.Leite joined Intel US and held positions as Latin America Programs Mgr. growing local teams from tenths to hundreds of employees, Internet Provider Marketing Manager, and Intel Labs Biz Mgr. for VOIP \& WiFi/WiMax. Leite moved to Brazil in 2002 as Latin America Product Mgr. and then Public Policy \& R\&D Director responsible for bringing Intel Labs to the region.Before joining Intel, Leite introduced AMD in Latin America by proposing strategy and then establishing first offices in Brazil and Argentina. Leite also founded mufti million-dollar new business in network and computer equipment (ICC) incorporated in Delaware, based in Texas, and with subsidiaries in Brazil. Leite also expended Latin America operations of New Jersey based Stonhard Inc. to Mexico.Leite holds a MBA from University of Texas and B.S. Industrial Engineering from University of Oklahoma. Leite was speaker at many global and regional events such as World Summit on Information Society (WSIS), United Nations International Telecom Union (ITU), Supercomm, Business Week L.A. Forum, Futurecom, Brazilian TV Association (ABTA), Mobile Fest, TEDx Singularity/FIAP, among others 